\title{
Non-marine algae of Australia: 4. Floristic survey of some colonial green macroalgae (Chlorophyta)
}

\author{
Timothy J. Entwisle and Stephen Skinner
}

\begin{abstract}
Entwisle, T.J. and Skinner, S. (Royal Botanic Gardens Sydney, Mrs Macquaries Road, Sydney NSW 2000, Australia) 2001. Non-marine algae of Australia: 4. Floristic survey of some colonial green macroalgae (Chlorophyta). Telopea 9(3): 725-739. Four genera in the Tetrasporales (Chlorophyta) are documented from Australia: Tetrasporidium javanicum Möbius is newly recorded, Tetraspora gelatinosa (Vaucher) Desvaux is confirmed for this country, and the distribution of Palmellopsis gelatinosa Korshikov and Parallela novae-zealandiae E.A.Flint are extended. A further gel-forming damp terrestrial taxon, Gloeocystis polydermatica (Kützing) Hindák (Radiococcaceae, Chlorococcales) is newly reported from Australia, and the conspicuous, gel-coated, Coleochaete areolata (Coleochaetaceae, Coleochaetales) is described as new to science. These six taxa are among the most commonly encountered colonial green macroalgae in Australian inland areas.
\end{abstract}

\section{Introduction}

This is the fourth in our series of floristic papers (Skinner \& Entwisle $2001 \mathrm{a}, \mathrm{b}, \mathrm{c}$ ) documenting freshwater macroalgae in Australia. Until recently, macroscopic colonial green-algae (Chlorophyta) collected in Australian inland waters were uncritically assigned to either Tetraspora Link or Palmella Lyngbye (see Day et al. 1995). There are at least three other genera of Tetrasporalean macroalgae represented in this country: Palmellopsis Korshikov, and Parallela E.A. Flint, first reported by Entwisle (1989), and Tetrasporidium Möbius, first reported by Entwisle et al. (1997). Published records of Tetraspora from Australia have been seldom substantiated by evidence of pseudoflagella and possibly referred, in part, to Palmellopsis and/or Tetrasporidium species. We can distinguish, with certainty, species in each of the four genera occurring in south-eastern Australian streams: Palmellopsis gelatinosa Korshikov, Parallela novae zealandiae E.A. Flint, Tetraspora gelatinosa (Vaucher) Desvaux, and Tetrasporidium javanicum Möbius. Two species of Palmella have been reported from Australian inland waters, P. hyalina Brébisson by Hardy (1913) from Victoria and P. mucosa Kützing by Playfair (1917) from New South Wales, but we have not been able to locate material of either record. Playfair's notebooks, held in the archives at NSW, have sketches and notes on parmelloid algae, but none appear to be vouchered in any of his spirit collection.

This research was funded through the NSW Biodiversity Strategy

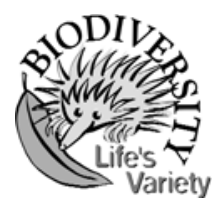


Our justification for including the other two genera discussed here, Gloeocystis and Coleochaete, arises from their similarity to the Tetrasporalean algae in field form. They also form visible, jelly-like, green colonies in fens, bogs, the faces of waterfalls and on damp ground. Coleochaete species are often encountered growing on host plants in similar habitats to Tetraspora and Tetrasporidium.

Gloeocystis has been narrowly circumscribed by Hindák (1978) to include only terrestrial taxa, so that the planktonic taxa described by Playfair (1916) are now referred to other genera and species among microalgal Chlorophyta. The Gloeocystis species described here is one example of those algae that form gelatinous masses in moist terrestrial and irregularly inundated habitats and has been included in the present paper to encourage interest in taxa from such habitats. Various other Chlorophyta may also be encountered: e.g. the desmid Cylindrocystis sp. collected from the edge of a walking track, Bathurst Harbour, Tasmania (Entwisle 2529); an unidentifiable palmelloid from Ku-Ring-Gai Chase, New South Wales (Entwisle 3015); and a Coccomyxa (probably C. gloeobotridiformis Reisigl.) from Hermons Road, near Dover, Tasmania (Weller, 20 Jul 1995 (MEL2069962)).

Quite a number of other algal groups, separate from the Chlorophyta, may, on occasions, develop gelatinous bodies around populations of cells. Some of the cells may show a grainy, uniform cytoplasm with no distinguishable organelles (under the light microscope) and are probably referrable to the Cyanobacteria. They frequently have cytoplasm that ranges in colour from washed-out blue or mauve through various shades of dull green to khaki, and the gel may be yellow, brown, bottle green or approaching black. Recent collections include Aphanothece spp. (Skinner \& Entwisle 2001a); as well as Chroococcus sp. aff. C. ercegovicii Komárek \& Anagnostidis on the mortar between sandstone blocks of a retaining wall in Annandale, NSW (Skinner 0290); and C. tenax (Kirchner) Hieronymus on the walls behind a waterfall, Blarney Ck near Morisset, N.S.W. (Cherry 336). Others may show discernible organelles, with plastids ranging in colour from yellowish green to golden-green. Such algae may belong to the Chrysophyta (see note on Tetrasporopsis fuscescens (A.Braun ex Kützing) Lemmermann after Parallela novae-zealandiae) or, if the cytoplasm is confined in siliceous cases, may be diatoms. Further collecting may reveal many other and diverse taxa exploiting a moist terrestrial or occasionally inundated habitat in Australia.

\section{Materials and methods}

As this is a floristic study (sensu Skinner \& Entwisle 2001a) in general type material has not been examined. Methods are documented in Skinner and Entwisle (2001a); herbarium abbreviations follow Holmgren et al. (1981).

\section{Key to the genera}

1 Colony a firmly attached gelatinous mass, with cells in filamentous axes ............................. 2

$1 *$ Colonies attached or free-floating, with non-contiguous cells ............................................... 3

2 Cells usually supporting a seta in a long sheath .................................................. Coleochaete

2* Cells without such setae, branches terminated by multicellular hairs ............ Chaetophora1

3 Colonies solid and often subaerial; cells in groups of one, two or four in concentric envelopes Gloeocystis

$3^{*}$ Colonies aquatic and diaphanous; cells not in envelopes, in various groupings ................. 4

4 Cells with pseudoflagella, in discrete groups of four .............................................. Tetraspora

$4^{*}$ Cells without pseudoflagella, in groups other than four ........................................................ 5 
5 Colonies of confluent ribbons; paired cells in parallel rows

$5 *$ Colonies saccate or bullate; cells not in parallel rows

6 Colonies lacunate; cells in one layer, in groups of multiples of four ............. Tetrasporidium

$6^{*}$ Colonies entire or lacerate; cells scattered through the matrix

Palmellopsis

\section{Tetrasporales: Tetrasporaceae}

\section{Tetraspora Link}

The cells in Tetraspora are usually grouped in fours, mostly towards the periphery of the colony, with pseudoflagella (not always apparent). Ettl \& Gärtner (1988) recognise four microscopic and three macroscopic species in Tetraspora. Six names had been ascribed previously to taxa possibly referrable to this genus for Australia (Day et al. 1995), and the status of these names is discussed below. One macroscopic species is outlined from Australian collections.

Tetraspora gelatinosa (Vaucher) Desvaux, Obs. pl. Angers 18 (1818).

Colony spherical, saccate or cumulous, variable in size from $0.5-2 \mathrm{~cm}$ for regular colonies, to $10 \mathrm{~cm}$ or more, usually $0.5-1.0 \mathrm{~mm}$ thick, irregular in shape, green (but sometimes mucilage becoming brownish). Cells spherical to slightly ellipsoid, $6-10 \mu \mathrm{m}$ diam., somewhat compactly arranged towards outside of matrix, pyrenoid single, subbasal, pseudoflagella not appearing to extend beyond mucilage. Akinetes spherical, brown, 9-15 $\mu \mathrm{m}$ in diameter. (Fig. 1).

Distribution and habitat: widespread throughout the world; known from scattered streams in mountain ranges of eastern Australia, mostly at higher altitudes. Occurs here in mostly pristine waters with macroalgae such as Spirogyra spp., Scytonema hofmannii C. Agardh, Oedogonium spp., Stigonema sp. and Batrachospermum antipodites Entwisle.

Notes: Although cells may sometimes appear to be irregularly arranged in a squash preparation, the cells tend to remain in groups of four (Fig. 1b), or less commonly two. The pseudoflagella are difficult to observe in preserved material but can always be seen under phase contrast (Fig. 1c), and usually stain well with toluidine blue. Pseudoflagella are immobile (they lack the two central microtubules of functional flagella) and zoospores and gametes apparently produce new flagella after shedding their pseudoflagella (Bold \& Wynne 1985). No motile cells were observed in this study.

The irregularly expanded colonies of T. gelatinosa differ from those of T. lubrica, which repeatedly split and often become perforated, and those of T. cylindrica (Wahlenberg) C. Agardh, which are cylindrical and tough in consistency. However Ettl \& Gärtner (1988) emphasise the differences in pyrenoid form as being the key separator of T. lubrica and T. gelatinosa. The fen-growing plants in Skinner 0165 were distinctly lacerate but lacked the distinctive pyrenoids of T. lubrica. In the absence of voucher specimens for Valerie May's records of T. lubrica (Roth) C. Agardh (May \& Powell 1986; May 1988) it is difficult to determine if these also fit better in T. gelatinosa as described here, although the collection sites (downstream from the Chaffey Dam on the Peel River, on the Northern Slopes, and Carcoar Dam in the Central Tablelands, N.S.W.) are appropriate. The Australian material we have examined differs little from the description for European T. gelatinosa and so we have maintained it as such. Whether these species distinctions are tenable cannot be gauged from the limited material examined.

Specimens examined: Queensland: Mt Coot-tha, 21 Apr 1983, Cribb 968.4 (BRI).

New South Wales: Northern Tablelands: Gloucester R., Barrington Tops National Park, Entwisle 1971, 10 Feb 1991, (MEL); fen beside Oaky R., Barokee rest area, Cathedral Rock National Park, 
Skinner NE026, 15 Apr 1997 (NEU) and Skinner 0165, 24 May 2000 (NSW); Oaky R., gate to national park, Cathedral Rock National Park, Skinner 0172, 24 May 2000 (NSW); Teatree Falls, Styx R., New England National Park, Skinner 0183, 24 May 2000 (NSW). South Coast: Minnamurra R., Minnamurra Falls, Entwisle 1890, 6 Feb 1991 (MEL); Douglas Ck, Pheasant Ground, Entwisle 1900, 6 Feb 1991 (MEL). Southern Tablelands: Sawpit Ck, Jindabyne-Mt Kosciuszko Rd, Entwisle 1575,12 Nov 1988 (MEL); Genoa R., Rockton, Entwisle 1846, 4 Feb 1991 (MEL);

Victoria: Mt Baw Baw, Ducker s.n., 11 Apr 1970 (MEL); Lake Mountain, Entwisle 2445, 30 Dec 1994 (MEL).

Historical note: There is a record of T. gelatinosa from Rosstown, Victoria (Hardy 1906), but no voucher specimen found in MEL.

The following taxa have been ascribed to Tetraspora in older literature for Australia:

T. bullosa (Roth) C. Agardh: Victoria (Watts 1887). Presumably Monostroma bullosum (Roth) Wittrock.

T. explanata C. Agardh: Sulphate, Queensland (Schmidle, 1896; Bailey 1898, 1913) = T. gelatinosa (following Ettl \& Gärtner1988).

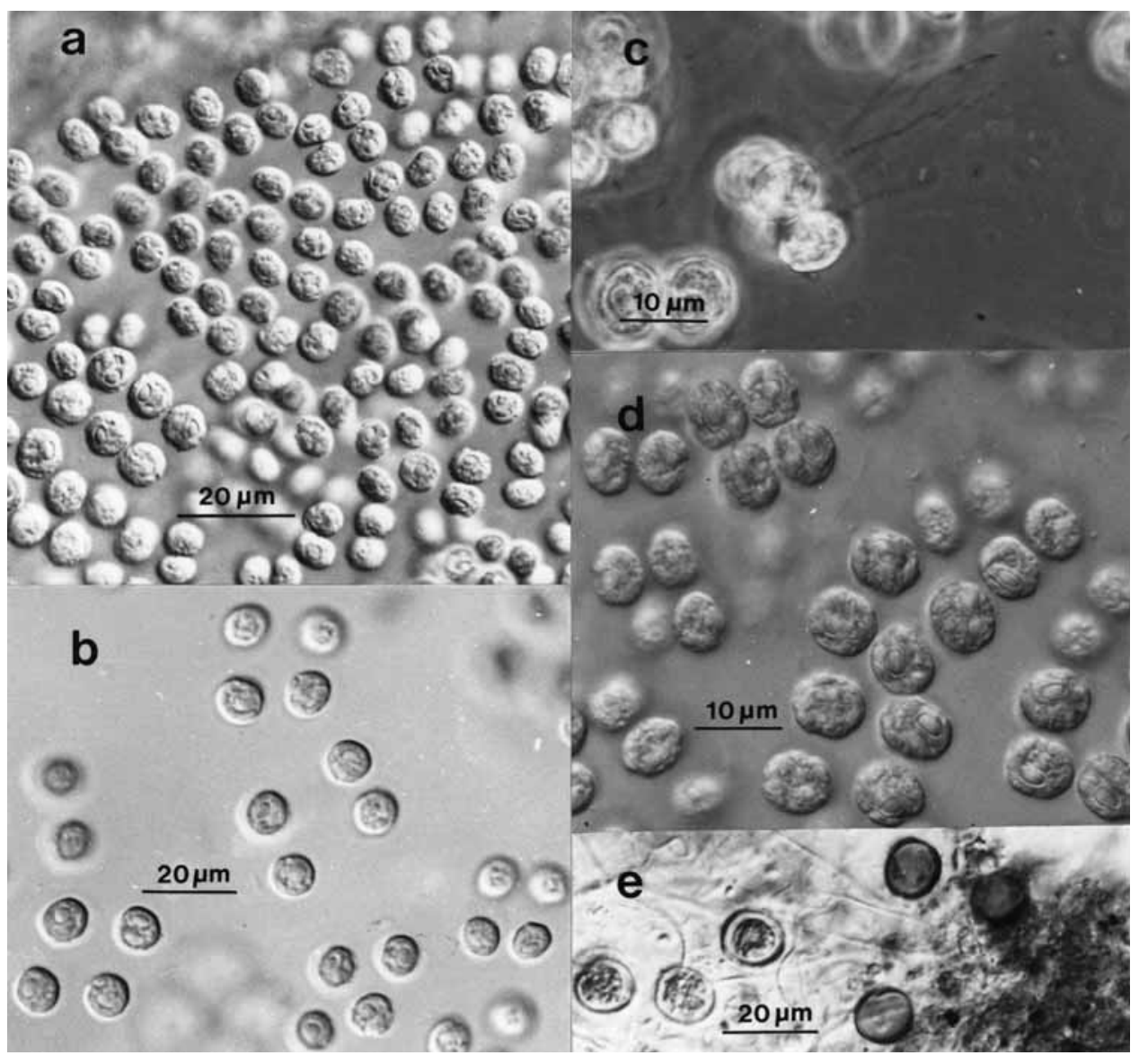

Fig. 1. Tetraspora gelatinosa (a-d, Entwisle 1890). a, cells in unsquashed mount. b, cells in squashed mount, in groups of four. c, cells under phase contrast showing pseudoflagella. $\mathbf{d}$, cells showing pyrenoids. e, empty akinetes (Entwisle 1900). 
T. intricata Berkeley \& Harvey: St Patrick's River, Tasmania (Harvey 1860, 1863; Sonder 1880). Only known from type locality. Bailey (1893) quotes Harvey's (1863, p. 342) description for this taxon, but the diagnosis says only that cells are 1/2000 of an inch, the whole thing is perforated, and the cells are in 4's, and as if in more or less one row. Bailey regretted that the state of the specimen (Gunn collection, but not held at NSW) did not allow further clarification.

T. lacustris Lemmermann: Yan Yean Reservoir, Victoria (West 1909) = T. lemmermannii Fott. Considered by West to be a stage in the life history of Sphaerocystis schroeteri Chodat (but see Fott 1972, p. 71).

In the absence of published descriptions (except for T. lacustris), none of these taxa can be reconciled with the species described in the present paper.

\section{Tetrasporales: Palmellopsidaceae}

\section{Tetrasporidium Möbius}

Tetrasporidium is characterised by its repeatedly perforated mature thallus, the cells being at the periphery, and the absence of pseudoflagella (although obscure motionless flagella are apparently often present). The overall morphology of the thallus and cells in all Australian collections is concordant with that described and illustrated for species of this genus by Ettl \& Gärtner (1988), who recognise three species: T. javanicum (the type species), T. lundii Pandey, Tiwari \& Pandy (1980) from India, and T. fottii from Czechoslavakia. Only T. javanicum has been found in Australia.

Tetrasporidium javanicum Möbius, Ber. dt. bot. Ges. 11: 122-123, t. 8 f. 6a-g (1893).

Colony irregularly net-like and folded, c. 1-3 cm long (but probably capable of growing much bigger), paper thin, spreading to $3 \mathrm{~cm}$ wide, green, with perforations of various sizes. Cells spherical to slightly ellipsoid, 5-13 $\mu \mathrm{m}$ in diameter, usually compactly arranged in single outer layer; chloroplast cup-like or lobed, pyrenoid central or peripheral; no reproductive structures observed with certainty. (Fig. 2).

Distribution and habitat: reported from ponds and stream edges in Java, Pakistan, India and France; in Australia known only from streams in north-eastern New South Wales and northern Queensland. In two of the New South Wales sites, Cladophora glomerata (Linnaeus) Kützing, indicative of hard water, was abundant. Other New South Wales collections are from 'soft' water.

Notes: The Manning River plants were profusely perforate and almost ribbon-like (reminiscent of Parallela novae-zelandiae E.A. Flint in the field), whereas those from Turon and Beatrice Rivers were less perforate and more sheet-like. Since colonies of Tetrasporidium javanicum are apparently entire and saccate when young (Fott et al. 1965), becoming perforate with age, these collections could represent plants of different ages. The minute flagella reported for T. fottii Couté \& Tracanna (Fott et al. 1965) and T. javanicum (Couté \& Tracanna 1981) were not observed, nor were thickwalled resting spores. The size of the cells and thalli fall within those reported for both T. javanicum and T. fottii. The pyrenoids in specimens from Manning River seem to be central in all cell orientations, whereas those of specimens from Turon and Beatrice Rivers are towards the periphery of the cell. Unfortunately, cell contents were too poorly preserved to allow accurate assessment of cell polarity with light microscopy. Some collections (Entwisle 1972, Skinner 0163) showed markedly lobed chloroplasts and so may be referable to T. fottii. However, all Australian populations have been tentatively referred to T. javanicum until the appropriate ultrastructural and life history studies can be carried out. 


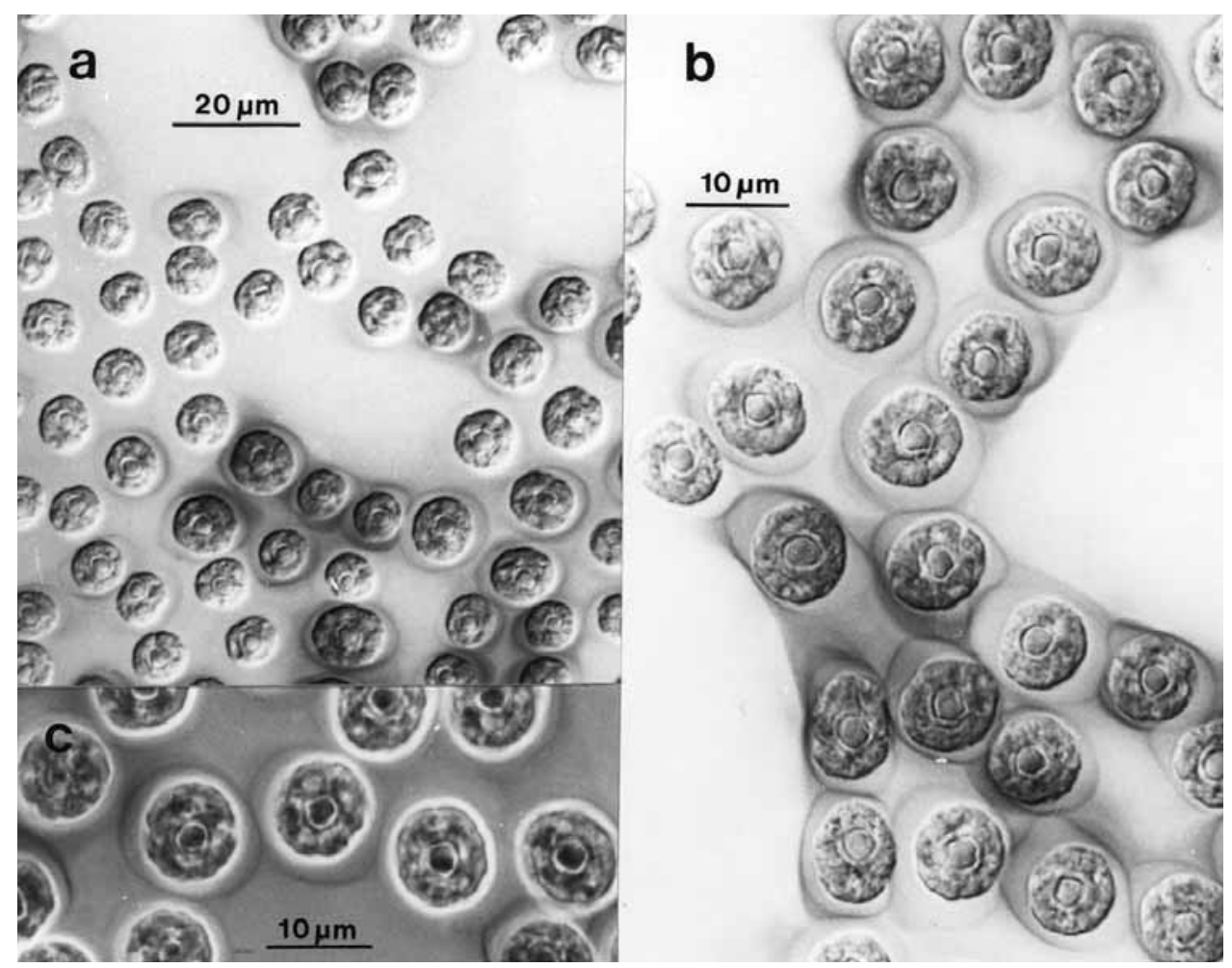

Fig. 2. Tetrasporidium javanicum (Entwisle 1982). a, perforations in thallus; b, cells lining perforations showing pyrenoid and separate gelatinous sheaths; c, cells under phase contrast, without pseudoflagella.

Specimens examined: Queensland: Beatrice R., Innesfail-Millaa Millaa Rd, Entwisle 2278,10 Sep 1993 (MEL).

New South Wales: Northern Tablelands: Manning R., Walcha-Gloucester Road, Entwisle 1966,10 Feb 1991, (MEL); Polblue Ck, Gloucester-Scone Rd, Entwisle 1972p.p, 10 Feb 1991 (MEL); Polblue Ck, Barrington Tops, Entwisle 2933,10 Jan 1999 (NSW); drain on Round Mountain Rd, Cathedral Rocks National Park, Skinner 0169, 24 May 2000 (NSW); Oaky R., Barokee rest area, Cathedral Rocks National Park, Skinner 0163, 24 May 2000 (NSW); Teatree Falls, Styx R., New England National Park, Skinner 0183, 24 May 2000 (NSW). Central Tablelands: Turon R., Sofala, Entwisle 1982,11 Feb 1991 (MEL).

\section{Palmellopsis Korshikov}

Palmellopsis is similar in form to Tetrasporidium but the cells are scattered throughout the colony and are not in regular groups. Ettl \& Gärtner (1988) place one microscopic and two macroscopic taxa in this genus. Entwisle's (1989) report of P. gelatinosa Korshikov from Victoria was the first for the genus from Australia.

Palmellopsis gelatinosa Korshikov, The Freshwater Algae of the Ukranian SSR. V. Subclass Protococcineae. Vacuolales and Protococcales, 66 (1953).

Colony cumulous, irregular in shape, up to $10 \mathrm{~cm}$ long, thin and spreading to $1 \mathrm{~cm}$ wide, green. Cells spherical to ellipsoid, 5-11 $\mu \mathrm{m}$ diam., sparsely arranged throughout matrix; chloroplast cup-shaped and almost filling cell, pyrenoid sub-basal. No reproductive structures seen with certainty. (Fig. 3). 
Distribution and habitat: reported from the Ukraine, Austria and Denmark; known in Australia from streams in eastern mountain ranges from Melbourne to south-eastern Queensland. Although it appears to be less common in winter, it is generally found in cold, fast-flowing streams. Occurs in almost pristine to moderately eutrophic streams, in the Nothocladus community of the Yarra catchment (sensu Entwisle 1989) also in streams with Tetrasporopsis fuscescens (A. Braun ex Kützing) Lemmermann and Tetrasporidium javanicum, or in more alkaline water with species such as Cladophora glomerata, Compsopogon coeruleus (Balbis) Montagne and Stigeoclonium tenue (C. Agardh) Kützing.

Notes: The description in Korshikov (1953) is quite broad, and encompasses our collections. Only the Yarra River basin populations have been studied from living and culture material (Entwisle 1989). The variety of habitats displayed by our collections supports the possibility that Australian material may be distinct from the European species, but present opinion is that the two are conspecific. Playfair's unpublished notes at NSW on his 1894 collection of Palmella mucosa from Collector in New South Wales, describe cells $8 \mu \mathrm{m}$ in diameter, but there is no extant specimen.

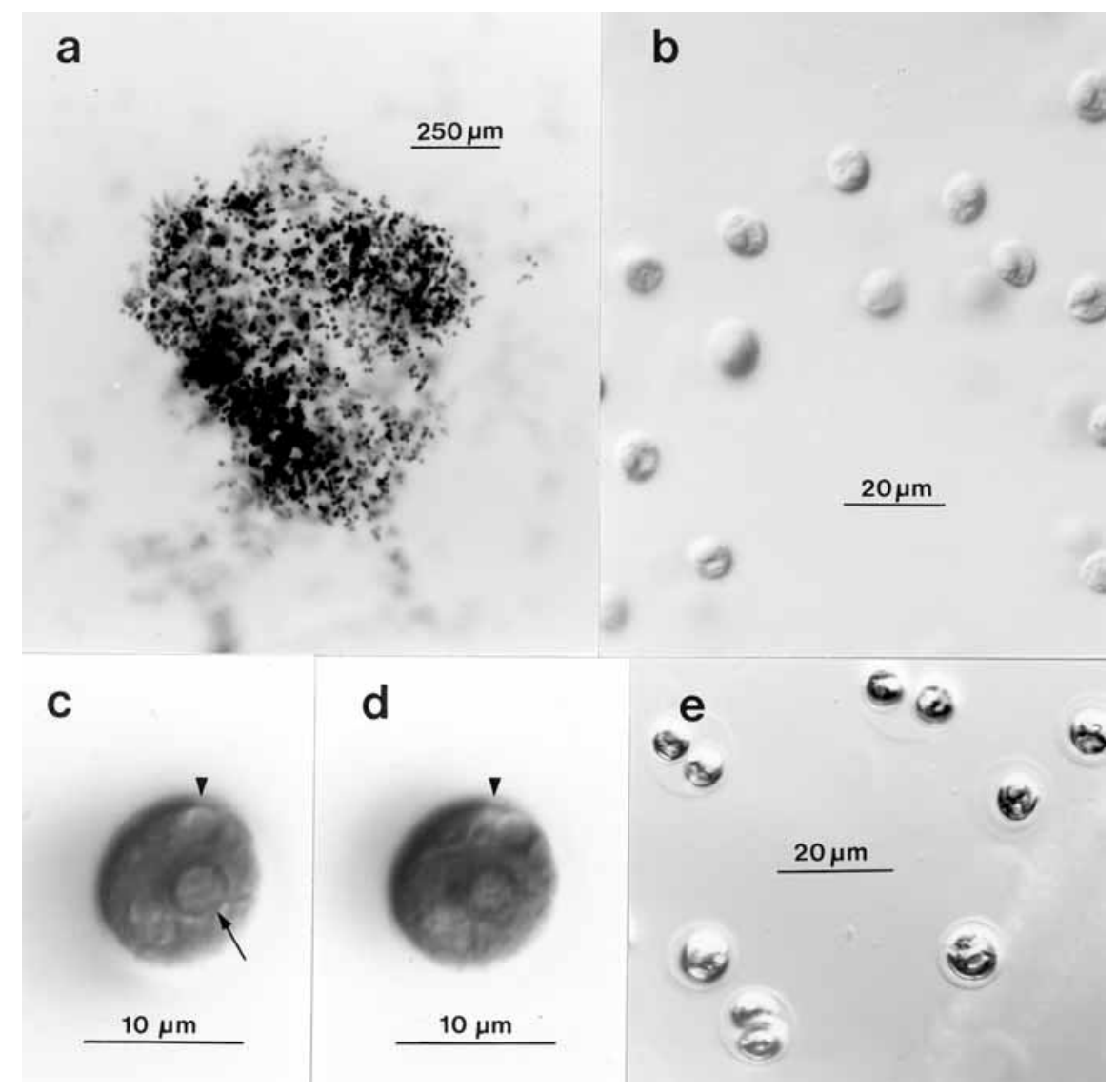

Fig. 3. Palmellopsis gelatinosa. a, habit of plant in culture (Entwisle 1400). b, sparse arrangement of cells in matrix (Entwisle 1035). c, d cell photographed at 5 second interval, showing pair of contractile vacuoles (arrowheads mark the same position in each photograph) and pyrenoid (arrow) (Entwisle 1157). e, gelatinous sheaths around cells in culture (Entwisle 1400). 
Palmellopsis muralis Bold and King, from USA, is microscopic, subaerial and has urnlike rather than cup-like chloroplasts and ellipsoid zoospores with a distinctive stigma (Bold et al. 1980). Palmellopsis texensis (Groover \& Bold) Ettl and Gärtner has a more consistent arrangement of the vegetative cells than $P$. gelatinosa, no contractile vacuoles, as well as usually two lateral pyrenoides.

Specimens examined: Queensland: $3 \mathrm{~km}$ from Killarney, towards Legume, creek into Condamine R., Entwisle 2804, 14 Jul 1997 (MEL).

New South Wales: North Coast: Tuntable Ck, $500 \mathrm{~m}$ start of walking track, road from Nimbin to Tuntable Falls, Entwisle 2825, 15 Jul 1997 (MEL). Northern Tablelands: Polblue Ck, Gloucester-Scone Rd, Entwisle 1972 p.p., 10 Feb. 1991 (MEL); Kuruah River, Washpool, Entwisle 1944, 8 Feb 1991 (MEL). Central Tablelands: Turon R., Sofala, Entwisle 1986, 11 Feb 1991 (MEL). Southern Tablelands: Spencers Ck, Jindabyne-Mt Kosciuszko Rd, Entwisle 1568, 11 Nov 1988 (MEL).

Victoria: Yarra River basin: see Entwisle (1989).

Parallela E.A. Flint

A distinctive monotypic genus differing from Radiofilum and Geminella (Ulothricales) in the absence of pyrenoids, the distinctly paired parallel plaited files of cells in the gelatinous mass, and the absence of cell walls in two halves. Flint's (1974) opinion was that Parallela belonged in the Chlorococcales rather than the Ulothricales; Ettl and Gärtner (1988) do not mention the genus.

Parallela novae-zealandiae E.A. Flint New Zealand J. Bot.12: 359 (1974).

Thallus a gelatinous streamer of plaited parallel rows of cells, up to several $\mathrm{cm}$ long, less than $1 \mathrm{~mm}$ wide or thick. Cells subglobose to lenticular, cell-wall indistinct, chloroplast laminate parietal, (7-)8-11 $\mu \mathrm{m}$ long, (3.5-)4-6(-10) $\mu \mathrm{m}$ diam. No definite reproductive structures, but single or small groups of large subglobose cells present. (Fig. 4 c, d).

Distribution and habitat: New Zealand, and North and South America; also in littledisturbed upland waterways in New South Wales, Victoria and the Northern Territory. Skinner 0185 formed fine wool-like skeins in shallow, cold water running over moss at the top of the falls.

Notes: These new collections closely match the descriptions in Flint (1974) and Entwisle (1989). This taxon warrants further investigation, to resolve if the variation noted by Entwisle (1989) is worthy of taxonomic recognition. Playfair includes in his notes, under 'old Sydney records', three possible collections of this taxon, variously ascribed to Palmodictyon viride Kützing (Auburn, No. 117), Radiophilum flavescens G.S. West (no locality, 22 Jul 1909, 'cells divide sideways') and Palmodactylon varium Nägeli (no locality, 3 Jan 1910, '...dividing sideways'). The dimensions and drawings of at least the latter two collections indicate affinities with Parallela, but we have been unable to locate vouchered material of these two and the material in Bottle 117 was not well preserved.

Specimens examined: New South Wales: Northern Tableland: Kuruah R., Washpool, Entwisle 1944, 8 Feb 1991 (MEL); Teatree Falls, Styx R., New England National Park, Skinner 0185, 24 May 2000 (NSW).

Northern Territory: Seventeen Mile Ck, near crossing from Katherine Gorge to Edith Falls, Nitmiluk National Park, Entwisle 2715, 2 Jun 1997 (MEL).

In addition to the four species of Chlorophytes reported here, another gelatinous colonial taxon was also encountered on rocks in cold water streams, the yellow-green Tetrasporopsis fuscescens (A. Braun ex Kützing) Lemmermann (Chrysosphaeraceae, Chrysophyta). First recorded in Australia from Victoria (Entwisle \& Anderson 1990), it has since been found in a few further Victorian localities and once in New South Wales (tributary of the Yowrie R., ford at TSR paddock Bourkes Rd, $1 \mathrm{~km} \mathrm{~S}$ of east gate to Walbilliga National Park, Skinner 0238c, 13 July 2000 (NSW)). 


\section{Chlorellales: Radiococcaceae}

\section{Gloeocystis Nägeli}

As defined by Hindák (1978) and Ettl \& Gärtner (1995), Gloeocystis is a small genus of three species, favouring damp terrestrial or epiphytic habitats, reproducing by autospores and similar in cell form to Coccomyxa Schmidle, from which it differs by possessing one pyrenoid in each cell and by having distinct concentric envelopes in the gel mass of the colonies.

Playfair (1916) describes several Gloeocystis species, but as all are planktonic and their colonies microscopic, these would now be reassigned to different genera in accordance with Hindák (1978). Playfair's notebooks contain some intriguing but now unconfirmable references to $G$. vesiculosa Nägeli. The organism described and illustrated in Playfair (1916) under that name is planktonic and probably refers to a microalga.

Gloeocystis polydermatica (Kützing) Hindák, F. Preslia, Praha 50: 8. (1978).

Gloeocapsa polydermatica Kützing, Tab. Phyc. 1(2): 15 (1846).

Thallus amorphous, mucilaginous, green to $30 \mathrm{~mm}$ high and at least $90 \mathrm{~mm}$ across, with scattered colonies of cells in concentric envelopes. Cells single, in pairs, or fours, oval to ellipsoidal (round in end view), 6.0-10 $\mu \mathrm{m}$ long and 3.6 - $4.8 \mu \mathrm{m}$ diam. and c. $2.5 \mu \mathrm{m}$ in end view at maturity, each in individual ellipsoidal envelopes inside several concentric spherical to ellipsoidal envelopes in the amorphous mucilage of the thallus; chloroplast cup-shaped or laminar, parietal, filling two-thirds of the cell, often on one side, with a single pyrenoid. Reproduction by 4-8 autospores, similar to vegetative cells, but of smaller dimensions. (Fig. $4 \mathrm{a}-\mathrm{b}$ ).

Distribution and habitat: in central Europe, Japan and New Guinea. Found in eastern Australia on soil in wet heathland or forest, probably widespread but seldom collected.

Notes: The Australian material fits comfortably within G. polydermatica as circumscribed by Hindák (1978) and Ettl and Gärtner (1995). Where the outer layers of the gel mass have dried out the concentric gel envelopes become much more distinct than in the inside colonies. Ling and Tyler (2000) record a larger form, as 'G. polydermatica forma' from Tasmania, but with minimal description and locality information. Various diatoms, green and blue-green algae take advantage of the mucilaginous nature of the thallus and grow in the surface layers.

Specimens Examined: Queensland: Rainbow Ck, Blackdown Tableland, Cribb 800.8, 2 Sep 1974 (BRI).

New South Wales: Central Tablelands: between Fairy Falls and railway station, Lawson, Coveny 18543, 26 Mar 2000 (NSW); Tomah Spur, adjacent to RBG Mt Tomah, Cherry 229, 28 Mar 2000 (NSW).

Victoria: Yarra Bend Park, Kew, slope on E side of Yarra R. opposite rear of Fairfield Hospital, J. Avram 1, 23 Aug 1996 (MEL).

\section{Coleochaetales: Coleochaetaceae}

\section{Coleochaete Brébisson}

A cosmopolitan genus of wide distribution and containing six well documented species (Szymanska \& Spalik, 1993); (Coleochaete orbicularis Pringsheim is a nomen dubium) and a number of other taxa are of less reliable status. Day et al. (1995) list eight species from Australia, including two described by Möbius (1892), C. baileyi and C. conchata. Coleochaete conchata is an uncommon species with distinctive small globose cells, most recently collected in Australia by A.B. Cribb (Bowen Creek, Hinchinbrook 


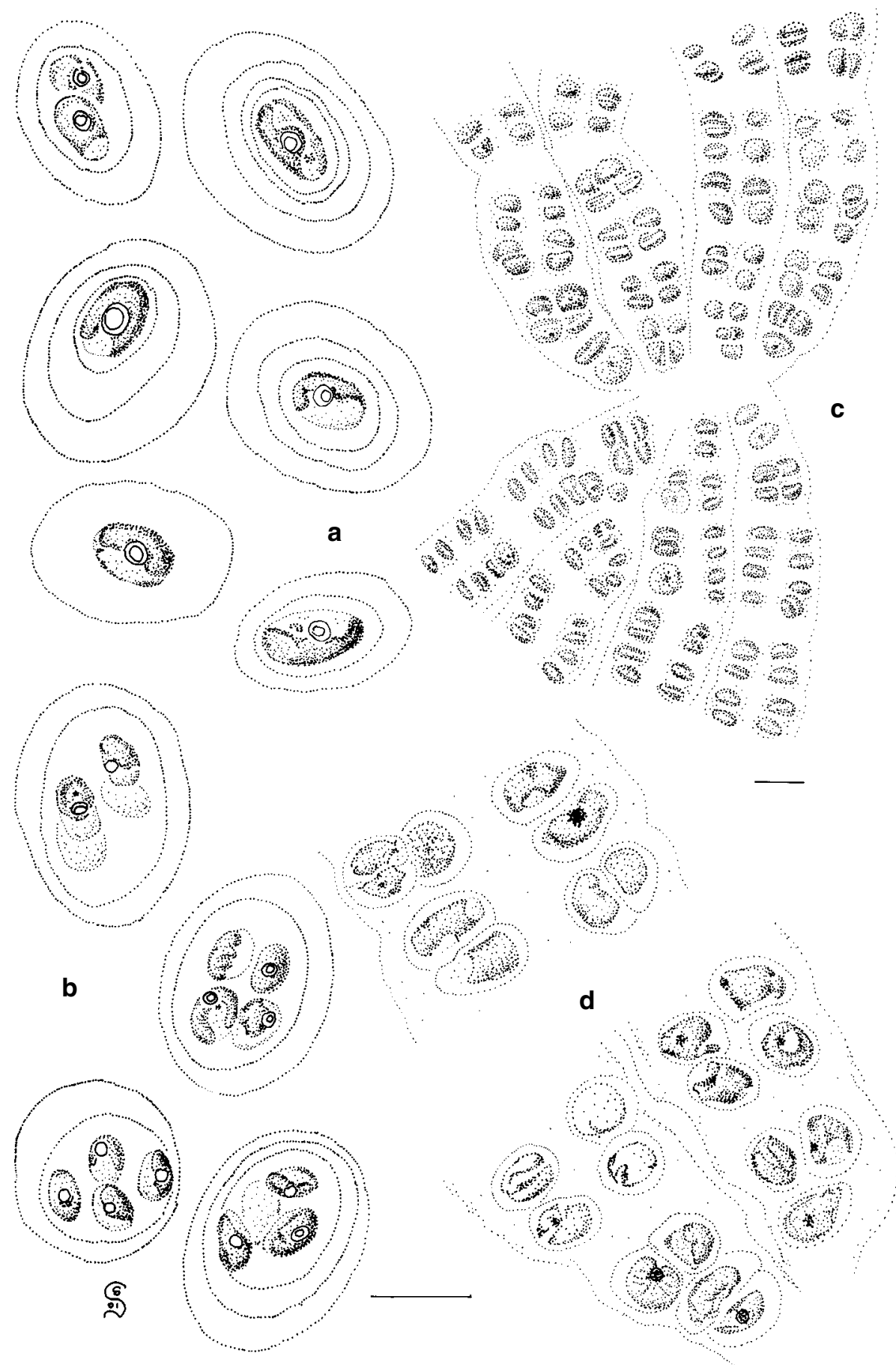

Fig. 4. Gloeocystis polydermatica (a, b Coveny 18543). a, vegetative cells; $\mathbf{b}$, reproductive cells, before release. Parallela novae-zealandiae (c, d Skinner 0185). c, thallus at plait node; d, vegetative cells. Scale bars: $a, b, d=10 \mu \mathrm{m} ; c=10 \mu \mathrm{m}$. 
Island, Queensland, Cribb 894.19, 25 Aug 1979 (BRI)). Coleochaete baileyi has been referred

C. pulvinata as a variety (Printz 1964). Szymanska (1990) tabulates and compares the typical dimensions for the Pringsheim species of Coleochaete, while other authors vary widely in dimensions that they apply to circumscribe taxa. Taking account of synonyms and recent revisions, Coleochaete in Australia includes C. divergens, C. pulvinata (including var. pulvinata and var. baileyii) C. conchata, C. nitellarum, C. scutulata and the new species described below. However we can verify only the new species $C$. areolata in this paper due to the lack of adiquate voucher material and/or other records and documentation.

\section{Coleochaete areolata Skinner \& Entwisle sp. nov.}

Thallus pulvinatus expansusque, amplior quam in C. pulvinata; spermocarpium intra cellulam suffultam oosporangii atque filamentas fulcrantes binatas a ramulis erectis adiectione; oosporum maturum cum spermocarpio areolatum.

Holotype: Beedelup Falls, 2.9 km NE of Vasse Hwy, Beedelup Falls National Park, 17 km W of Pemberton, Western Australia, J.H.Ross 3944, 3 Dec 1996 (MEL).

Colonies gelatinous, sometimes forming a large mat several $\mathrm{cm}$ across, green to orangebrown, on rock or epiphytic. Basal system a radiating disc of outwardly expanding quadrate cells with a parietal chloroplast, one pyrenoid, about $25 \mu \mathrm{m}$ long, 12-20 $\mu \mathrm{m}$ diam. and 18-22 $\mu \mathrm{m}$ thick, from which arise one or more erect ramifying processes. Erect axes radiating, branching alternately and successively; cells subglobose and upwardly inflated in apical parts of axes, to cylindrical in the lower two thirds of axes, mostly with a seta and collar, 15-30(-50) $\mu \mathrm{m}$ long, 12-18 $\mu \mathrm{m}$ diam.; chloroplast lamellate parietal with 1, 2 (or rarely more) pyrenoids; seta collar narrow, even, with slightly flared end, $30 \mu \mathrm{m}$ or more long, 2-3 $\mu \mathrm{m}$ diam. Monoecious. Antheridia formed terminally on branches close to branches bearing oogonial initials, 2 to 6 or 8 together, conical with a slightly drawn out end, opening terminally and expanding when empty, c. $12 \mu \mathrm{m}$ long, c. $6 \mu \mathrm{m}$ diam. Spermatozoid has a chloroplast. Oogonia formed terminally on outer branches, but gradually displaced as growth continues in axis, flask-shaped with a long sinuous colourless trichogyne, 20-24 mm across the inflated base, $80-90 \mu \mathrm{m}$ long, of which trichogyne is c. $60 \mu \mathrm{m}$ long, 7-8 $\mathrm{mm}$ diam. After fertilization, a wall forming at the base of the trichogyne, the oospore then swelling and suffultory cell producing a second lateral cell which grows around the oospore, continuing to divide; other close-by filaments, often from the same axis, also producing cells which in clasping the oospore invest it in an envelope. Oospore 60-75 $\mu \mathrm{m}$ diam. at maturity. Resulting spermocarp supported by two or three pairs of branches of the axis, round, making a coat of pillow-shaped cells, 75-120 $\mu \mathrm{m}$ diam. At maturity, outer wall of oospore and inside walls of enveloping cells thickened and staining golden brown giving whole structure the areolate appearance for which the species is named. Zoosporangia as terminal or lateral cells of erect axes, pyriform, opening by rupture, 40-45 $\mu \mathrm{m}$ long, 15-20 $\mu \mathrm{m}$ in diameter; zoospore with cup-shaped chloroplast and basal pyrenoid, occupying the lower two thirds of the sporangium, c. $25 \mu \mathrm{m}$ long, c. $18 \mu \mathrm{m}$ diam. (Fig. 5).

Distribution and habitat: attached to rocks in fast-flowing streams through eucalypt forest, also found forming conspicuous cushions on the upper cells of Characeae. The Western Australian specimens demonstrate increasing maturity in oospores and consequent deterioration of the vegetative thallus as summer temperatures rise: December collections show all stages of sexual reproduction, while January collections have well matured oospores among dead or dying vegetative structures. This response may be to seasonal drying rather than temperature, as material collected in a mild, dry autumn from northern New South Wales (Skinner s.n.) shows mature 
oogonia. Zoosporangia are very rare on sexually reproducing plants, although common in TJE 2978.

Etymology: The specific epithet, areolata, describes the areolate decoration of the mature spermocarp.

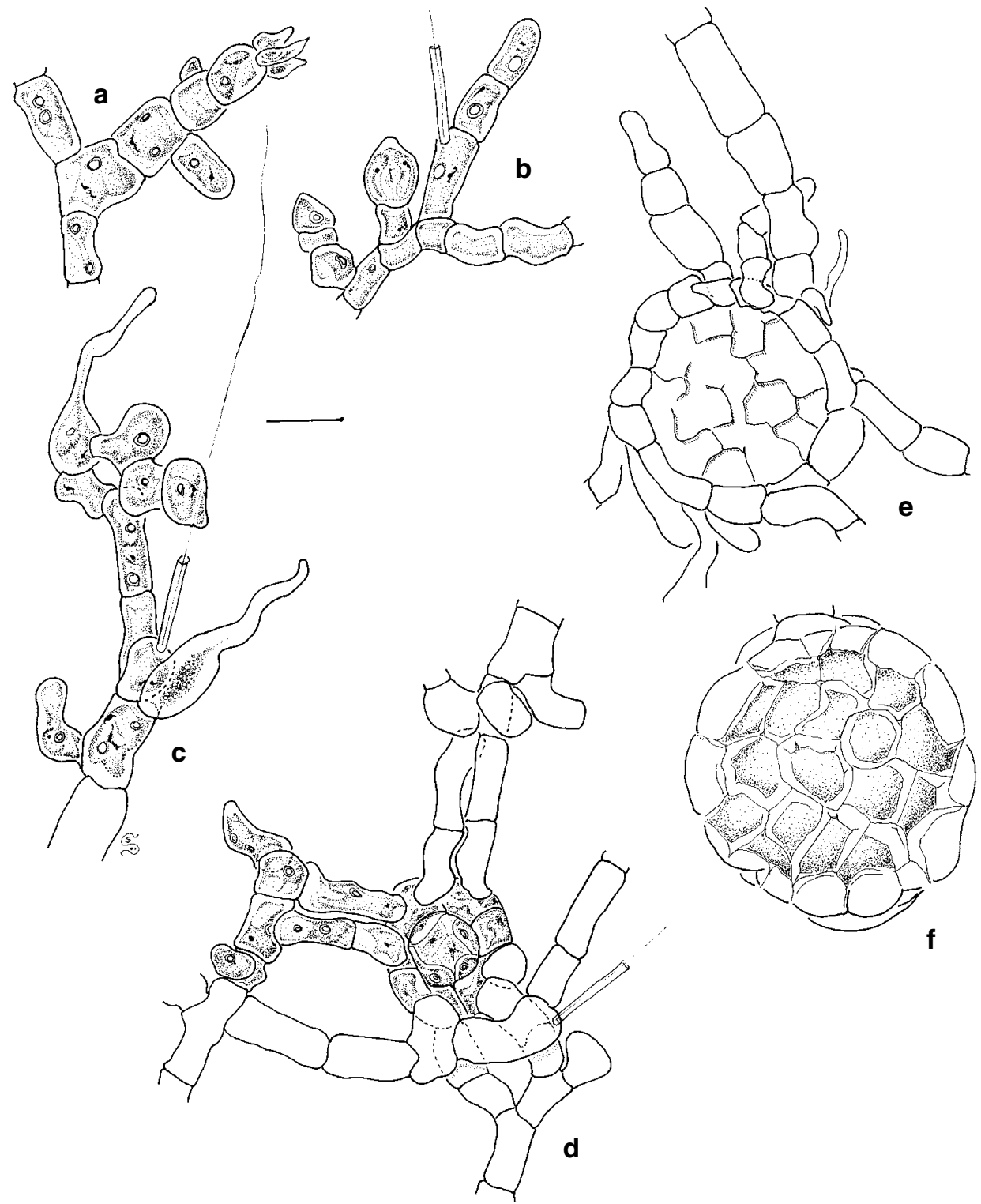

Fig. 5. Coleochaete areolata sp. nov. (a-f, Ross 3944). a, antheridia; b, zoosporangium; c, upper axis, with just fertilised oogonium (above) and unsuccessful oogonium (below); d, developing oospore with paired supporting filaments; e, maturing sporocarp, showing developing flanges; $\mathbf{f}$, mature areolate sporocarp. Scale bar $=25 \mu \mathrm{m}$. 
Notes: Coleochaete areolata is close to C. divergens Pringsheim and C. pulvinata A. Braun in growth form, but generally has larger cell dimensions and distinctive areolate thickenings of the oosporial wall and the bases of the envelope cells which make up the spermocarp.

The descriptions of C. pulvinata var. baileyi by Möbius (1892), Bailey (1893) or Printz (1964) are very similar and suggest similarity between C. pulvinata var. baileyi and C. areolata in vegetative form. Coleochaete pulvinata var. baileyi is described as having the oospore almost free and naked among the vegetative filaments without the investment of cells or the inward investiture of membranous flanges described for $C$. conchata. Möbius (1892) described zoosporangia forming in series in the terminal regions of axes in C. baileyi. In material of C. areolata examined here the zoosporangia are solitary and terminal or subterminal and may be in the same part of an axis, although not in series. Stages in spermocarp and oospore development correspond to those described by Oltmanns (1922) and Fritsch (1935) for C. pulvinata, but the paired supporting filaments are unique to $C$. areolata. Mature spermocarps with oospores having pronounced areolate golden-brown thickening, are not described for other cushionforming Coleochaete species.

Other specimens examined: New South Wales: North Coast: Boggy Ck, above Minyon Falls, Minyon Drive, off Nimbin-Goonengerry rd, Entwisle 2978, 14 Jul 1999 (NSW). Northern Tablelands: Barleyfields Lagoon, Uralla, Skinner s.n., 30 May 1996 (NSW).

Victoria: Dandenong area, Devilbend Reservoir, south of Mornington, M. Mackey AEB, 19 Mar 1991 (MEL).

Western Australia: Gloucester National Park, The Cascades, Lefroy Brook, Glauders Rd, $1.8 \mathrm{~km}$ E of its junction with Pemberton-Northcliffe road, $5.7 \mathrm{~km} \mathrm{~S}$ of Pemberton, Ross 3941, 3 Dec 1996 (MEL); Beedelup Falls, Beedelup National Park, off Vasse Highway, c. $16 \mathrm{~km} \mathrm{~W}$ of Pemberton, Entwisle 2405, 6 Jan 1994 (MEL); Beedelup Falls National Park, Beedelup Falls, 2.9 km NE of Vasse Hwy, 17 km W of Pemberton, Ross 3945, 3 Dec 1996 (MEL); Deep River, Fernhook Falls, Beardmore Road, Mt Frankland National Park, c. 24 km WNW of Walpole, Entwisle 2391, 5 Jan 1994 (MEL); South Dandalup R., Torrens Rd, 2.2 km from Delpark Rd, c. 14 km ENE of Pinjarra, near North Dandalup, Entwisle 2384, 5 Jan 1994 (MEL).

One collection of a gelatinous, partly pulvinate and partly disc-forming Coleochaete with small cells, possibly referable to $C$. conchata, but not maturely reproductive, has been made on the New England Tableland (Skinner 0186). There are also non-pulvinate species in Australia (e.g. C. scutulata and C. nitellarum, see Day et al. 1995) which are not considered further here.

\section{Acknowledgments}

Thanks are due to Wayne Cherry for his companionship on the field trip to the Northern Tablelands and his enthusiastic collections in various parts of the state, Robert Coveny for collections throughout N.S.W., and the directors of MEL, and BRI for specimen loans. The authors wish to acknowledge the financial support from the National Parks and Wildlife Service through the New South Wales Biodiversity Strategy. We would also like to thank Marion Westmacott, Lesley Elkan and Catherine Wardrop for their advice and support with illustration. The comments and advice of referee Dr Gerry Kraft were warmly appreciated. 


\section{References}

Bailey, F.M. (1893) Contributions to the Queensland Flora. Queensland Freshwater Algae. Bot. Bull. Dept Agric., Queensland, No.6.

Bailey, F. M. (1898) Contributions to the Queensland Flora. Queensland Freshwater Algae. Bot. Bull. Dept Agric., Queensland, No. 15.

Bailey, F. M. (1913) Comprehensive Catalogue of Queensland Plants, both Indigenous and Naturalised, 2nd ed. (Qld Gov.: Brisbane).

Bold, H. C. \& Wynne, M. J. (1985) Introduction to the Algae. Structure and Reproduction, (PrenticeHall: Englewood Cliffs, N. J.).

Bold, H. C., Slocum, R. D., King, J. M. \& MacEntee, F. J. (1980) Palmellopsis muralis sp. nov. (Chlorophyceae, Tetrasporales, Palmellaceae). J. Phycol. 17: 9-14

Couté, A. \& Tracanna, B. (1981) Sur la présence en France de Tetraspordium javanicum Moebius (Chlorophyta, Euchlorophyceae, Tetrasporales) et sa position systématique. Crypt. Algol. 2: 209-219.

Cribb, A.B. (1976) Some Algae from Blackdown Tableland. Queensland Nat., 21: 132 -133.

Day,S.A., Wickham,R.P., Entwisle,T.J. \& Tyler, P.A. (1995) Bibliographic Checklist of Non-Marine Algae in Australia. Flora of Australia Supplementary Series No.4. (ABRS: Canberra).

Entwisle, T. J. (1989) Macroalgae in the Yarra River basin: flora and distribution. Proc. Roy. Soc. Vict. 101: 1-76.

Entwisle, T.J. \& Anderson, R.A. (1990) A re-examination of Tetrasporopsis (Chrysophyceae) and the description of Dermochrysis gen. nov. (Chrysophyceae): a monostromatic alga lacking cell walls. Phycologia 29: 263-274.

Entwisle, T.J., Sonneman, J.A. \& Lewis, S.H. (1997) Freshwater Algae in Australia (Sainty \& Associates: Sydney).

Ettl, H. \& Gärtner, G. (1988) Chlorophyta II in Pascher, A. (ed.) Susswasserflora von Mitteleuropa. (Gustav Fischer Verlag: Stuttgart).

Ettl, H. \& Gärtner, G. (1995) Syllabus der Boden-, Luft-, und Flechtenalgen. (Gustav Fischer Verlag: Stuttgart).

Fott, B. (1972) Chlorophyceae (Grünalgen), Ordnung: Tetrasporales. Das Phytoplankton des Süsswassers, Systematik und Biologie 3: i-x,1-116, $47 \mathrm{pl}$.

Fott, B., Nováková, M. \& Kalina, T. (1965) Morphology, reproduction and occurrence of a tropical alga, Tetrasporidium javanicum Möbius (Chlorophyceae). Preslia 37: 380-386.

Flint, E.A. (1974) Parallela, a new genus of freshwater Chlorophyta in New Zealand. N.Z. J. Bot., 12: 357-363.

Fritsch, F.E. (1935) The Structure and Reproduction of the Algae I (University Press: Cambridge).

Hardy, A. D. (1906) The fresh-water algae of Victoria. Part III. Victorian Nat. 23: 18-22, 33-42.

Hardy, A. D. (1913) Some algae of the Zoological Gardens, Melbourne. Victorian Nat. 30: 89-95, pl. 5.

Harvey, W. H. (1860) Algae.Pp282-343. in: Hooker, J.D. Flora of Tasmania. vol. 2. Monocotyledons and Acotyledons (L. Reeve: London).

Harvey, W. H. (1863): Phycologia Australasica. vol. 5. (L. Reeve: London).

Hindák, F. (1978) The genus Gloeocystis (Chlorococcales, Chlorophyceae) Preslia, Praha 50: 3-11.

Holmgren, P.k., Keuken, W \& Schofield, E.K. (1981) Index Herbariorum, Part 1. 'The Herbaria of the World'. 7th Edition. (Bohn, Schellema \& Holkema: Utecht) [Regnum Vegetabile 106: 1-452]

Ling, H.U. \& Tyler, P.A. (2000) Australian Freshwater Algae Bibliotheca Phycologica, 105 (J. Cramer: Berlin).

Korshikov, O. A. (1953) The Freshwater Algae of the Ukranian SSR. V. Sub-class Protococcineae. Vacuolales and Protococcales. (Znachnik Prisnovodnitch Vodorestei, URSR: Kiev).

May, V. (1988) Algae of Carcoar Dam, New South Wales, Australia. Cunninghamia 2: 1-7.

May, V. \& Powell, J. M. (1986) Algae of the Peel River and the newly constructed Chaffey Dam, New South Wales, Australia. Cunninghamia 1: 503-536.

Möbius, M. (1892) Ueber einige brasilianische Algen. Ber. Deutsch. Bot. Ges. 10: 17-26.

Oltmanns, K. (1922) Morphologie und Biologie der Algen. Vol. 1. (Gustav Fischer Verlag: Jena).

Pandey, R. S., Tiwari, G. L. \& Pandey, D. C. (1980) Observations on two species of Tetrasporidium Moebius (Chlorophyta, Tetrasporales). Nova Hedwigia 32: 779-787.

Playfair, G.I. (1916) Australian Freshwater Phytoplankton Proc. Linn. Soc. NSW, 41: 823-852.

Playfair, G. I. (1917) Census of New South Wales fresh-water algae. Pp. 219-262 in Maiden, J.H. \& Betche, E. (eds) A Census of New South Wales Plants, Suppl. 1. (Government Printer: Sydney). 
Printz, H. (1964) Die Chaetophoralen der Binnengewässer. Hydrobiologia 24: 1-376.

Schmidle, W. (1896) Süsswasseralgen aus Australian. Flora, Jena 82: 297-313.

Skinner, S. \& Entwisle, T.J. (2001a) Non-marine Algae of Australia: 1. Survey of Colonial Blue-green Macroalgae (Cyanobacteria). Telopea 9(3): 573-579.

Skinner, S. \& Entwisle, T.J. (2001b) Non-marine Algae of Australia: 2. Telopea 9(3): 685-712.

Skinner, S. \& Entwisle, T.J. (2001c) Non-marine Algae of Australia: 3. Telopea 9(3): 713-723.

Sonder, O. (1880) Algae Australianae hactenus cognitae. Pp 1-42 in Müller, F.von Fragmentorum

Phytographie Australiae, Indices Plantarum Acotyledonarum Complectens, suppl. To vol. II. (Government Printer: Melbourne).

Szymanska, H. (1990) On dimensions of Typical forms of Coleochaete (Charophyta) species described by Pringsheim. Taxon 39: 572-575.

Szymanska, H. and Spalik, K. (1993) Typification of the names enumerated in Pringsheim monograph of Coleochaete (Charophyceae). Archiv fur Hydrobiologie, Suppl. Bd 98 (Algological Studies 70): 29-37.

Watts, H. (1887) Some recent additions to our knowledge of microscopic natural history. Victorian Nat. 3: 133-137.

West, G.S. (1909) The algae of the Yan Yean Reservoir, Victoria: a biological

and ecological study. J. Linn. Soc., Bot. 39: 1-88.

Manuscript received 4 April 2001

Manuscript accepted 2 November 2001 